1 A Precambrian proximal ejecta blanket from Scotland

2 Kenneth Amor ${ }^{1}$,

3 Stephen P. Hesselbo ${ }^{1}$

4 Don Porcelli ${ }^{1}$

5 Scott Thackrey ${ }^{2}$

6 John Parnell ${ }^{2}$

71 Department of Earth Sciences, University of Oxford, Parks Road, Oxford OX1 3PR.

82 Department of Geology \& Petroleum Geology, Meston Building, King's College, Aberdeen, AB24 3UE.

10 Ejecta blankets around impact craters are rarely preserved on Earth. Although

11 impact craters are ubiquitous on solid bodies throughout the solar system, on Earth

12 they are rapidly effaced and few records exist of the processes occurring during

13 emplacement of ejecta. The Stac Fada Member of the Precambrian Stoer Group of

14 Scotland has previously been described as volcanic in origin. However, shocked

15 quartz and biotite provide evidence for high-pressure shock metamorphism, whilst

16 chromium isotope values and elevated abundances of the platinum group metals and

17 siderophile elements, indicate addition of meteoritic material. Thus the unit is re-

18 interpreted as of impact origin. The ejecta blanket reaches $>\mathbf{2 0} \mathbf{m}$ in thickness, and

19 contains abundant dark green, vesicular, devitrified glass fragments. Field

20 observations suggest that the deposit was emplaced as a single fluidized flow, formed

21 by an impact into water-saturated sedimentary strata. The continental geological

22 setting and presence of groundwater, makes this deposit an analogue for Martian

23 fluidized ejecta blankets. 
Introduction

Impact craters are a major feature on planetary bodies, but few examples exist on

26 the Earth's surface due to rapid erosion or burial. To date only the proximal ejecta from

27 Ries (von Engelhardt et al., 1995) and the Albion Formation from Chicxulub (Pope et al.,

28 1999) have been comprehensively described.

The Stac Fada Member (SFM) forms a distinctive unit within the Mesoproterozoic

30 Stoer Group, the oldest sedimentary rocks of the Torridonian Supergroup in NW Scotland.

31 It has previously been described as volcanic in origin (Stewart, 2002; Lawson, 1972;

32 Sanders and Johnson, 1989; Young, 1999; 2002) and can be traced for $50 \mathrm{~km}$ along a N-S

33 aligned outcrop (Fig. 1a). Bedding dips $\sim 20^{\circ}$ to the west and the Stoer Group is assumed to

34 underlie the Mesozoic Minch Basin. The group lies unconformably on the Archaean

35 Lewisian Gneiss, and sediments were deposited in a semi-arid environment (Stewart,

36 1982), blanketing a paleo-landscape with relief of $\leq 300 \mathrm{~m}$. A Pb-Pb isochron for a

37 stromatolitic limestone approximately $10 \mathrm{~m}$ above the SFM at location 7 (Fig. 1a) gives an

38 age for the Stoer Group of $1199 \pm 70$ Ma (Turnbull et al., 1996). At this same location, the

39 SFM is underlain by $>500 \mathrm{~m}$ of interbedded fluviatile and alluvial sandstones, and ripple-

40 marked lacustrine siltstones and mudstones.

41 The supposedly volcanic origin for the SFM has always been enigmatic because it is

42 a unique event within the Torridonian and no other related volcaniclastic sediments are

43 known and no vent has been located. Here we present evidence for the impact origin of the

44 SFM, whose outcrop we interpret as a chord section through the continuous ejecta blanket

45 surrounding an impact crater. Rapid burial has preserved the SFM in almost pristine

46 condition. 
Field Observations

The SFM marks the junction between dominantly fluviatile siltstone and sandstone

49 immediately below, and relatively deepwater $(\sim 40 \mathrm{~m})$ lacustrine facies above (Stewart and

50 Parker, 1979; Stewart, 2002; Fig.1c). The lake deposits, which extend for about $100 \mathrm{~m}$

51 above the SFM, become shallower upwards, evidenced by the appearance of small-scale

52 ripple marks and desiccation cracks towards the top. The succession therefore shows a

53 sudden re-configuration of the regional drainage pattern (Stewart, 1982), which we attribute

54 to the formation of a post-impact lake.

55 The SFM has a maximum thickness of $22.4 \mathrm{~m}$ at location 6 , generally waning in

56 thickness both to the north and south (Fig. 1b). The unit is essentially homogenous at each

57 location, containing up to $50 \%$ devitrified melt clasts varying in size from $\sim 2-5 \mathrm{~mm}$ at site

581 and between $\sim 2-15 \mathrm{~mm}$ at locations 6 and 7 . The matrix is poorly sorted, ranging from

59 clay to coarse sand size and includes rounded clasts of mudstone, sandstone and gneiss up

60 to $0.5 \mathrm{~m}$ diameter. This unit can be described as a suevite (a polymict clastic-matrix breccia

61 with cogenetic melt particles). A finer grained, decimeter-thick zone at the base of the

62 member makes a sharp contact with the underlying stratum. The upper surface at field

63 location 6 is marked by a pronounced undulating $10 \mathrm{~cm}$ thick bed of fine grained sandstone.

64 At location 7, large rafts of sandstone have been ripped up and in some instances heavily

65 deformed while SFM material has been injected for several meters between bedding planes

66 of the underlying strata, indicating lateral movement approximating from the SW (cf.

67 Stewart, 2002). A strong component of fluidized flow in the SFM is inferred from the

68 shallow decline in thickness of the unit, the presence of a thin basal shear zone equivalent

69 to layer $2 \mathrm{a}$ in pyroclastic flows (Sparks et al., 1973), the suggestion of a preferred 
70 horizontal orientation of melt clasts at some locations, and the injection of SFM between

71 bedding planes of underlying strata. The lack of sorting and structureless fabric suggests the

72 flow froze rapidly. Vertical, undeformed fluid escape pipes (also seen in Ries crater ejecta)

73 and now filled with authigenic feldspar are observed at most locations. Fluid inclusions in

74 the feldspar contain water trapped at up to $200{ }^{\circ} \mathrm{C}$ as determined following the method of

75 Goldstein and Reynolds (1994), indicating formation from hot volatiles escaping from

76 within or beneath the flow.

77 Shock Metamorphism

78 Thin sections from samples collected at locations 1, 6 and 7 (Fig. 1a) were inspected

79 with a petrologic microscope for planar fractures or planar deformation features (PDFs).

80 The provenance of the Stoer Group is considered to be from local Lewisian Gneiss

81 (Stewart, 1990), and consequently grains showing a single set of planar features were

82 ignored as possibly of regional metamorphic origin (although none were observed in the

83 sandstone or gneiss beneath the SFM). Decorated (with arrays of small fluid inclusions

84 along the original fracture plane) and non-decorated forms of PDFs are found in quartz

85 grains throughout the matrix of the SFM (Figs. 2 A-C), although these become rare towards

86 the base. In one example, shocked quartz occurs inside a melt fragment. The spacing of the

87 lamellae is at sub-micrometer to micrometer scales and the PDFs are straight, continuous

88 and parallel, unlike those produced from regional compressional metamorphism, which are

89 typically spaced $>10 \mu \mathrm{m}$ apart and are discontinuous, often wavy in appearance. PDFs were

90 identified in 25 quartz grains from 9 thin sections. Of these $28 \%$ have 3 or more sets of

91 intersecting, parallel lamellae. The PDF plane to grain ratio is 2.36 and $69 \%$ of the PDFs

92 were indexed. The crystallographic orientations of PDFs were measured relative to the c- 
93 axis using conventional U-stage microscope and stereonet techniques (Fig. 3). These data

94 clearly illustrate the development of preferred angles corresponding to the PDFs most

95 commonly found in shocked quartz, and the distribution does not show the bell-shaped

96 curve expected from regional metamorphic deformation. The very closely spaced lamellae,

97 and the appearance of PDFs parallel to crystal faces $\{22 \overline{4} 1\},\{10 \overline{1} 3\}$ and $\{10 \overline{1} 2\}$, imply

98 shock pressures at the higher end (> $20 \mathrm{GPa}$ ) of their range of formation (7-35 GPa)

99 (Stöffler and Langenhorst, 1994). Biotite also exhibits shock metamorphism (Fig. 2D),

100 displaying characteristic kink bands of shocked sheet silicates (Hörz and Ahrens, 1969).

101 The presence of shocked quartz is widely accepted as evidence of hypervelocity

102 impact, since formation pressures exceed the highest grade of regional metamorphism, $\sim 5$

$103 \mathrm{GPa}$ (Grieve, 1987). The thin sections contain low numbers of shocked quartz grains, $\sim 5-6$

104 per slide at locations 6 and 7 and $\sim 2$ per slide at location 1, when compared to the 50 grains

105 per slide found in the crystalline clasts of Ries ejecta (von Engelhardt and Bertsch, 1969).

106 The relative scarcity of shocked quartz may be due to the presence of extensive

107 groundwater in the sandstones. Porous, water-saturated sand or sandstone behaves

108 distinctively during shock metamorphism. Shock waves are attenuated by collapsing pore

109 space and movement on grain boundaries, thereby reducing the volume of rock subjected to

110 the pressures in which PDFs form in quartz (Kieffer and Simonds, 1980; Melosh, 1989).

111 Post-shock melting occurs at lower pressures in sand and sandstones (15-20 GPa)

112 compared to non-porous crystalline rocks (50-60 GPa) (Stöffler, 1984) aided by heat

113 generated by movement at intergrain boundaries. High water-vapour pressure lowers the

114 solidus temperature and promotes melting. Shocked material may also have become diluted

115 by entrainment of loose regolith in a ground-hugging flow. 


\section{Accretionary Lapilli}

135 located.

\section{Geochemistry}

The SFM was evidently emplaced as a single unit with no sharp distinction between a surface flow and airfall components. At location 5, the SFM directly overlies gneiss; if the absence of the Stoer Group sandstone is due to a local topographic high of unknown elevation at the time of emplacement, then this is evidence for either airfall deposition or a rapidly moving flow capable of climbing minor gradients. Core-type accretionary lapilli are observed towards the top of the SFM at the thickest locations, with a gradational transition from the suevite to lapillite. The lapilli are composed of aggregates of lithic grains surrounded by shells of clay grade material, often oval in cross section, with a haematitic coating and typically $\sim 7 \mathrm{~mm}$ diameter. The lapilli appear indistinguishable from volcanic accretionary lapilli derived from an eruption plume, and therefore presumably formed by a similar process of aggregation. The lapilli observed are intact, implying the presence of a water-saturated plume cloud (Gilbert and Lane, 1994), since lapilli forming from a dry cloud are more likely to have broken on contact with the ground. Above the lapillite at location 6 are several $\sim 20 \mathrm{~cm}$ thick, normally graded beds which are interpreted as deposits of late-stage ground surges generated by a collapsing plume. Accretionary lapilli appear in other impact deposits, such as the Ries suevite (Graup, 1981) and Chicxulub ejecta (Pope et al., 1999). Carbonate accretionary lapilli also occur in the Devonian Alamo breccia (Warme et al., 2002), ejecta from another impact into a wet target for which no crater has yet been

We have analysed samples collected from locations 1, 6, and 7 for trace elements, including platinum group elements (PGE) and have also analyzed samples from location 7 
139 for chromium isotopes. All geochemical data are tabulated in supplementary data files. Two

140 'background' rocks, a sandstone from near the base of the section at location 7, and a

141 gneiss, were also sampled. Samples were crushed and digested using a standard

$142 \mathrm{HF} / \mathrm{HNO}_{3} / \mathrm{HCl}$ digestion. PGEs were concentrated following the method of Jarvis et al.

143 (1997) using a cation exchange column in $\mathrm{HCl}$ media and adjusting reagent volumes as

144 appropriate. In $0.5 \mathrm{M} \mathrm{HCl}$ rock matrix cations are retained on the resin while the PGEs,

145 which form anionic chloro-complexes, are washed through. This method returned yields >

$14695 \%$ for Rh, Pd, Ir, Pt and Au when normalized using a 10ppb multi-element laboratory

147 solution. Our results for a dunite reference material DTS-1 are comparable to published

148 data (Gladney et al., 1991). Trace element abundances were measured on a Perkin-Elmer

1496100 DRC quadrupole ICP-MS.

150 There is a clear enrichment of Cr, Ni, and Co in the SFM (188, 403 and 28 ppm,

151 respectively) relative to the country rocks (72, 40 and $11 \mathrm{ppm})$. An enrichment of $\mathrm{Cr}$ and $\mathrm{Ni}$

152 in the SFM has also been reported by Young (1999; 2002). We interpret this as evidence

153 for a meteoritic component since these elements are found in higher abundances in some

154 groups of meteorites relative to crustal rocks. After subtraction of local values, $\mathrm{Ni} / \mathrm{Cr}$ ratios

155 of 2.9-3.9 fall within the range of an ordinary chondrite $(\mathrm{Ni} / \mathrm{Cr} \sim 2-7)$ and appear to rule out

156 an iron projectile $(\mathrm{Ni} / \mathrm{Cr}>3000)$. Ni/Cr values for the Stoer Group sandstone are 0.33-0.6,

157 typical for continental crust.

158 Chromium isotope data were obtained after isolating $\mathrm{Cr}$ by cation exchange

159 chromatography and measuring isotope ratios on a Nu-instrument MC-ICP-MS. Ratios

160 were internally normalized by applying an exponential law and using a ${ }^{50} \mathrm{Cr} /{ }^{52} \mathrm{Cr}=$

1610.051859 (Shields et al., 1966) and were compared against NIST SRM979 Cr standard. Cr 
162 isotope data are expressed using the epsilon notation where $\varepsilon^{53} \mathrm{Cr}=$

$163\left[\left\{\left({ }^{53} \mathrm{Cr} /{ }^{52} \mathrm{Cr}\right)_{\text {sample }} /\left({ }^{53} \mathrm{Cr} /{ }^{52} \mathrm{Cr}\right)_{\text {ref }}-1\right\} \times 10000\right]$. All meteorite groups measured to date have

164 been shown to have an excess of ${ }^{53} \mathrm{Cr}$ relative to terrestrial samples (Lugmair and

165 Shukolyukov, 1998), and the presence of meteoritic material in impact crater deposits can

166 be demonstrated from Cr isotope measurements (e.g. Koeberl et al., 2007). Our data (Fig.

$1674 \mathrm{~A})$ shows an $\varepsilon^{53} \mathrm{Cr}$ value of $+0.26( \pm 0.06)$ for the $\mathrm{SFM}$ as compared to $+0.004( \pm 0.1)$ for

168 the Lewisian gneiss and $+0.007( \pm 0.1)$ for the Stoer Group sandstones and is unequivocal

169 evidence for a meteoritic component.

170 There is an enrichment of PGEs (Fig. 4B) in the SFM relative to surrounding

171 sediments at locations 6 and 7, consistent with a meteoritic contribution. Location 1 has no

172 significant PGE elevation, indicating a heterogeneous redistribution of a meteoritic

173 component within the SFM. When CI-normalized (Fig. 4C), the SFM samples display a

174 flatter, more chondritic profile than the country rock. Concentrations of Pt and Ir are

175 correlated (slope $\left.=1.88, \mathrm{r}^{2}=0.95\right)$, as are $\mathrm{Rh}$ and $\mathrm{Pd}\left(\right.$ slope $\left.=0.37, \mathrm{r}^{2}=0.93\right)$, indicating a

176 coherence from a controlling PGE-rich mineral component or process. Other PGE+Au

177 inter-element ratios show little correlation, suggesting re-mobilization either through

178 weathering, diagenesis or hydrothermal fluids. Incorporation of a local picrite into

179 sediments at location 7 (Stewart, 2002) may account for the high background abundances

180 ( $6 \mathrm{ng} / \mathrm{g}$ Ir) in the sandstones. The indigenous PGE component combined with possible

181 mobilization make the PGE character of the projectile uncertain.

\section{Implications and Conclusions}

183 Cr isotope values, PGE and siderophile element data together with shocked quartz

184 provide unequivocal evidence for a meteorite impact origin for the SFM. The high 
185 abundance of melt clasts and low numbers of shocked quartz grains, imply extensive

186 melting, and indicate volatile-rich target rocks; probably groundwater in the Stoer Group

187 sands. Field observations suggest the SFM was emplaced from a dense, turbulent, vapour-

188 borne ground flow most likely initiated by ballistic deposition. This is consistent with the

189 suggestion that impacts into volatile-rich sediments produce a large volume of rapidly

190 expanding vapour, entraining ejected material and creating a turbulent ground flow (Kieffer

191 and Simonds, 1980). The rapid expansion of the vapour phase assists the dispersal of

192 impact melt produced in the crater, and accounts for the high proportion of melt clasts

193 found throughout the SFM.

194 Accretionary lapilli and thin graded beds towards the top of the unit are interpreted

195 as evidence for atmospheric interaction with ejecta. However, in this instance groundwater

196 appears to have played a dominant role in controlling the major ejecta blanket morphology

197 lending support to models favouring fluidization of ejecta by vaporization of sub-surface

198 volatiles (Carr et al., 1977; Mouginis-Mark, 1979), rather than interaction with the

199 atmosphere (Schultz and Gault, 1979; Barnouin-Jha and Schultz, 1996). Ejecta fluidization

200 is evident at Chicxulub and Ries impact craters (Kenkmann and Schönian, 2006; von

201 Engelhardt et al., 1995; Osinski, 2004).

202 The continental setting of the Stoer Group sandstones and inferred sub-surface

203 volatiles are similar to sedimentary environments ascribed to Mars, making the SFM an

204 analogue for single-layer ejecta surrounding Martian impact craters for which an impact

205 into a volatile-rich target is inferred.

206

207 Acknowledgements 
208 We are grateful for the assistance with analyses from Dave Waters (U-stage microscope), Norman

209 Charnley (SEM), John Arden and Cees-Jan De Hoog (ICP-MS), Dave Sampson (Drafting) and

210 Ingrid Hesselbo (ably provided field assistance). Darren Mark provided the fluid inclusion

211 observations. Referees Nadine Barlow, Christian Koeberl and Jay Melosh are thanked for their

212 constructive critical comments and Stephen Moorbath for scientific discussion.

214 References Cited

215 Barnouin-Jha, O.S., Schultz, P.H., 1996, Ejecta entrainment by impact-generated ring vortices:

216 Theory and experiments. Journal of Geophysical Research, v.101, E9, p.21099-21116.

217 Carr, M.H., Crumpler, L.S., Cutts, J.A., Greeley, R., Guest, J.E., Masursky, H., 1977, Martian impact

218 craters and emplacement of ejecta by surface flow. Journal of Geophysical Research, v.82,

219 p.4055-4065.

220 Gilbert, J.S., Lane, S.J., 1994, The origin of accretionary lapilli. Bulletin of Volcanology, v.56, p.398221411.

222 Gladney, E.S., Jones, E.A., Nickell, E.J., Roelandts, I., 1991, 1988 Compilation of Elemental

223 Concentration Data for USGS DTS-1, G-1, PCC-1 and W-1. Geostandards Newsletter, 15, p.199224396.

225 Goldstein, R.H., Reynolds, T.J., 1994, Systematics of fluid inclusions in diagenetic minerals: SEPM, 226 Short Course Notes 31.

227 Gratz, A.J., Fisler, D.K., Bohor, F., 1996, Distinguishing shocked from tectonically deformed quartz

228 by the use of the SEM and chemical etching. Earth and Planetary Science Letters, v.142, p.513-

229521.

230 Graup, G., 1981, Terrestrial chondrules, glass spherules and accretionary lapilli from the suevite,

231 Ries Crater. Earth and Planetary Science Letters, v.55, p.407-418.

232 Grieve, R.A.F., 1987, Terrestrial impact structures. Annual Review of Earth and Planetary Science, 233 v.15, p.245-270.

234 Hörz, F., Ahrens, T.J., 1969, Deformation of experimentally shocked biotite. American Journal of 235 Science, v.267, p.1213-1229. 
236 Jarvis, I., Totland, M.M., Jarvis, K.E., 1997, Determination of the platinum-group elements in

237 geological materials by ICP-MS using microwave digestion, alkali fusion and cation-exchange

238 chromatography. Chemical Geology, v.143, p.27-42.

239 Kenkmann, T., Schönian, F, 2006, Ries and Chicxulub: Impact craters on Earth provide insights for

240 Martian ejecta blankets. Meteoritics \& Planetary Science, v.41, p.1587-1603.

241 Kieffer, S.W., Simonds, C., 1980, The role of volatiles and lithology in the impact process. Reviews

242 of Geophysics and Space Physics, v.18, p.143-181.

243 Koeberl, C., Shukolyukov, A., Lugmair, G.W., 2007, Chromium isotopic studies of terrestrial impact

244 craters: Identification of meteoritic components at Bosumtwi, Clearwater East, Lappajärvi, and

245 Rochechouart. Earth and Planetary Science Letters, v.256, p.534-546.

246 Lawson, D.E., 1972, Torridonian volcanic sediments. Scottish Journal of Geology, v.8, p.345-362.

247 Lugmair, G.W., Shukolyukov, A., 1998, Early solar system timescales according to 53Mn-53Cr

248 systematics. Geochimica et Cosmochimica Acta, v.62, p.2863-2886.

249 Melosh, H.J., 1989, Impact cratering: a geologic process. Oxford monographs on geology and 250 geophysics; No. 11.

251 Mouginis-Mark, P.J., 1979, Martian fluidized crater morphology - Variations with crater size, latitude,

252 altitude, and target material. Journal of Geophysical Research, v.84, p.8011-8022.

253 Osinski, G.R., 2004, Impact melt rocks from the Ries structure, Germany: an origin as impact melt

254 flows? Earth and Planetary Science Letters, v.226, p.529-543.

255 Pope, K.O., Ocampo, A.C., Fischer, A.G., Alvarez, W., Fouke, B.W., Webster, C.L., Vega, F.J.,

256 Smit, J., Fritsche, A.E., Claeys, P., 1999, Chicxulub impact ejecta from Albion Island, Belize. Earth

257 and Planetary Science Letters, v.170, p.351-364.

258 Sanders, I.S., Johnston, J.D., 1989, The Torridonian Stac Fada Member; an extrusion of fluidised

259 peperite? Transactions of the Royal Society of Edinburgh: Earth Sciences, v.80, p.1-4.

260 Schultz, P.H., Gault, D.E., 1979, Atmospheric effects on Martian ejecta emplacement. Journal of

261 Geophysical Research, v.84, B13, p.7669-7687. 
262 Shields, W.R., Murphy, T.J., Catanzaro, E.J., Garner, E.L., 1966, Absolute Isotopic Abundance

263 Ratios and the Atomic Weight of a Reference Sample of Chromium. Journal of Research of the

264 National Bureau of Standards-A, 70(2), 193-197.

265 Sparks, R.S.J, Self, S., Walker, G.P.L., 1973, Products of Ignimbrite Eruptions. Geology, v.1, 266 p.115-118.

267 Stewart, A.D., Parker, A., 1979, Palaeosalinity and environmental interpretation of red beds from

268 the late Precambrian ('Torridonian') of Scotland. Sedimentary Geology, v.22, p.229-241.

269 Stewart, A.D., 1982, Late Proterozoic rifting in NW Scotland: the genesis of the ' Torridonian'.

270 Journal of the Geological Society, v.139, p.413-420.

271 Stewart, A.D., 1990, Geochemistry, provenance and climate of the upper Proterozoic Stoer Group

272 in Scotland. Scottish Journal of Geology, v.26, p.89-97.

273 Stewart, A.D., 2002, The later proterozoic torridonian rocks of Scotland: their sedimentology,

274 geochemistry and origin. Memoir (Geological Society of London), No. 24, p.5-21.

275 Stöffler, D., 1984, Glasses formed by hypervelocity impact. Journal of Non-Crystalline Solids, v.67, 276 p.465-502.

277 Stöffler, D., Langenhorst, F., 1994 Shock metamorphism of quartz in nature: I. Basic observation 278 and theory. Meteoritics, v.29, p.155-181.

279 Turnbull, M.J.M., Whitehouse, M.J., Moorbath, S., 1996, New isotopic age determinations for the

280 Torridonian, NW Scotland. Journal of the Geological Society, v.153, p.955-964.

281 Warme, J.E., Morgan, M., Kuehner, H.C., 2002, Impact-generated carbonate accretionary lapilli in 282 the Late Devonian Alamo Breccia. in Catastrophic events and mass extinctions: impacts and 283 beyond (eds. Koeberl, C. and MacLeod, K.G.), Geological Society of America Special Paper 356, 284 p.489-504.

285 Young, G.M., 1999, Some aspects of the geochemistry, provenance and palaeoclimatology of the

286 Torridonian NW Scotland. Journal of the Geological Society, v.156, p.1097-1111.

287 Young, G.M., 2002, Stratigraphy and geochemistry of volcanic mass flows in the Stac Fada 288 Member of the Stoer Group, Torridonian, NW Scotland. Transactions of the Royal Society of 289 Edinburgh: Earth Sciences, v.93, p.1-16. 
290 von Engelhardt, W., Bertsch, W., 1969, Shock induced planar deformation structures in quartz from 291 the Ries crater, Germany. Contributions Mineralogy and Petrology, v.20, p.203-234.

292 von Engelhardt, W. Arndt, J., Fecker, B., Pankau, H.G., 1995, Suevite breccia from the Ries crater, 293 Germany: Origin, cooling history and devitrification of impact glasses. Meteoritics, v.30, p.279-293. 
Fig. 1 Location map (modified from Young, 1999) and log (from Stewart, 2002) for Stac Fada Member (SFM). SFM thicknesses are from our own observations. Size and location of the crater are unknown, although it can be inferred to lie either east or west of the thickest deposit at location 6 . Injection structures at location 7 infer emplacement from the SW. To the east, erosion has removed the Stoer Group, while the Minch Sea to the west (bounded by the Minch and Coigach faults) is the site of a Mesozoic sedimentary basin.

Fig. 2 Photomicrographs and SEM images of shocked minerals. (A) Qtz from SFM (location 7) with two sets of intersecting, decorated PDFs; primary evidence for shock metamorphism from an impact. Qtz grains exhibiting PDFs typically have an angular outline. (B) Qtz with two sets of closely spaced, intersecting lamellae, indicating shock pressures at the higher end of their range of formation. (C) JEOL 840A SEM image. Slides were HF vapour etched for 5 mins following the procedure of Gratz et al.(1996). Qtz grain from SFM (location 7) with 3+ sets of intersecting PDFs. The N-S lineations are probably tectonic in origin - widely spaced $>10 \mu \mathrm{m}$, discontinuous and not perfectly straight. (D) Biotite with kink bands, characteristic of shock metamorphism in sheet silicates.

Fig. 3 Absolute frequency histogram of PDF angles in quartz measured relative to the c-axis $\left(3^{\circ}\right.$ bins) after von Engelhardt and Bertsch (1969). The planes characteristic of impact-induced shock are well developed.

Fig. 4 (A) $\varepsilon^{53} \mathrm{Cr}$ isotope profile for SFM (location 7). The anomalous excess of ${ }^{53} \mathrm{Cr}$ in the SFM clearly indicates a meteoritic component in the unit. (B) Iridium profile (location 6). Over an order of magnitude increase in Ir relative to the basement gneiss is present in the impact layer. High levels of Ir in the Stoer Group sandstones below may be due to re-mobilization or incorporation of a weathered picrite. (C) CI normalized PGE data for the SFM and target rocks, ordered by increasing condensation temperature. The suevite at location 6 has a higher abundance of PGE relative to basement rocks and shows a more chondritic pattern. 


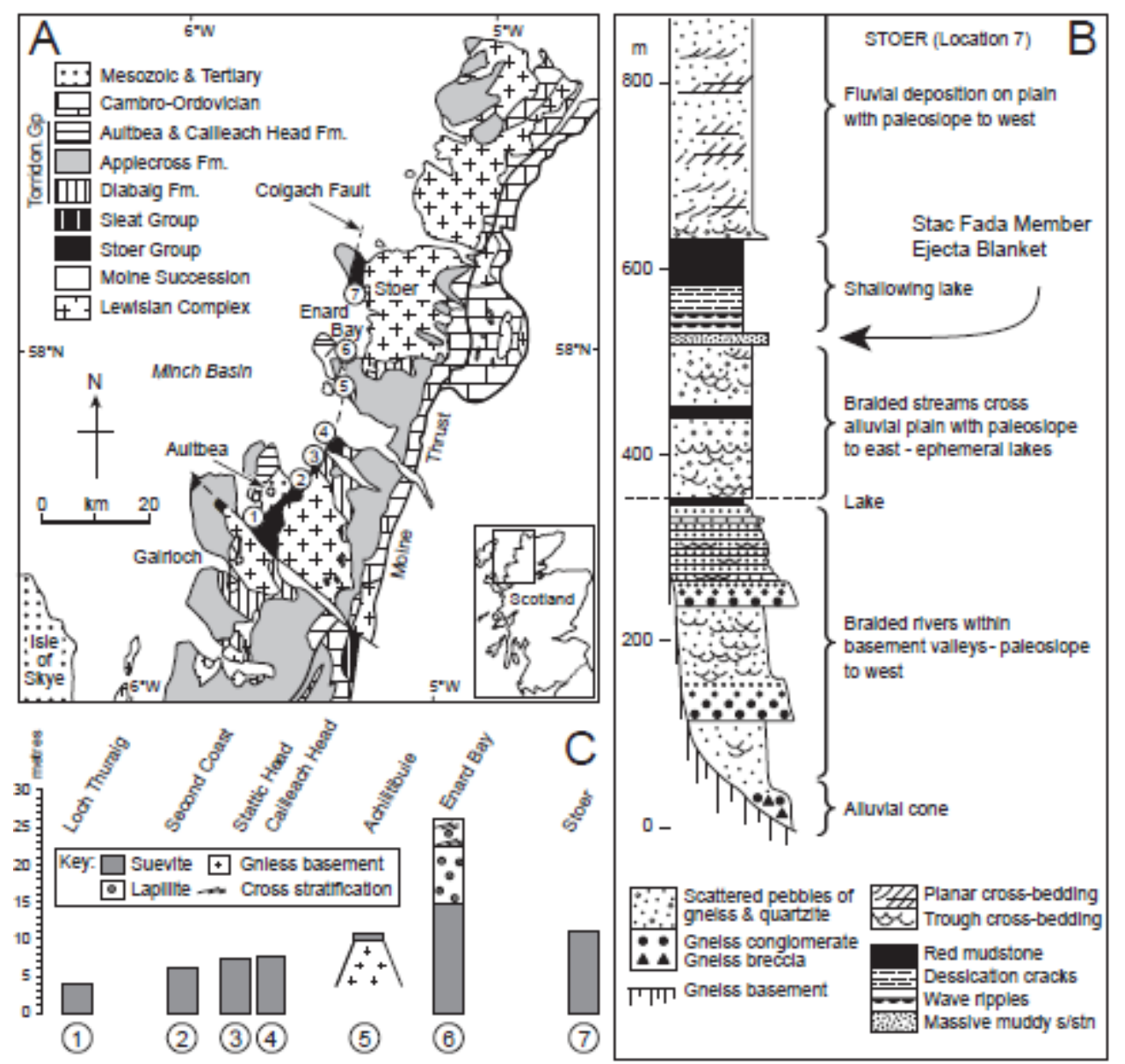

Fig 1. 

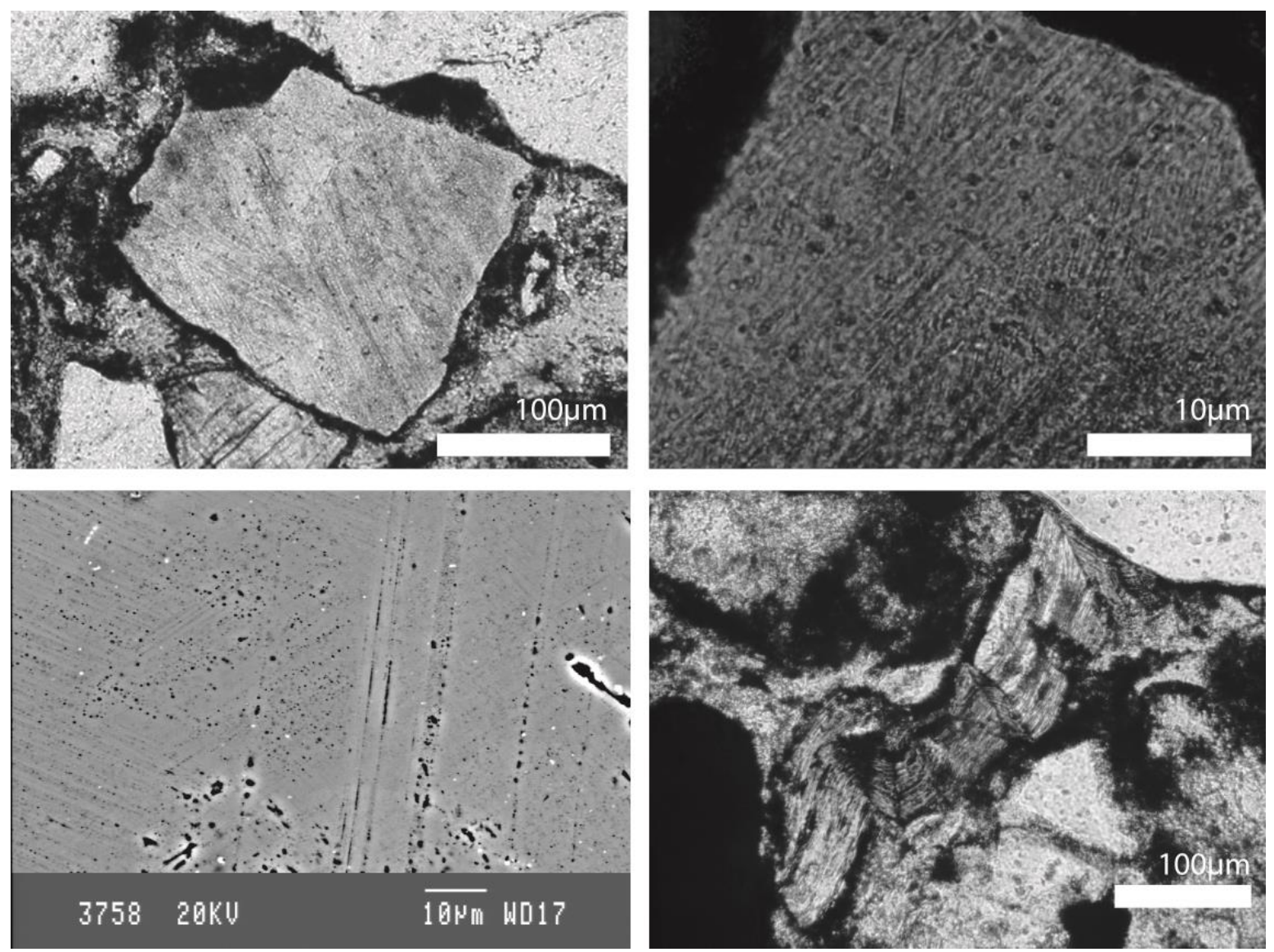

Fig 2. 


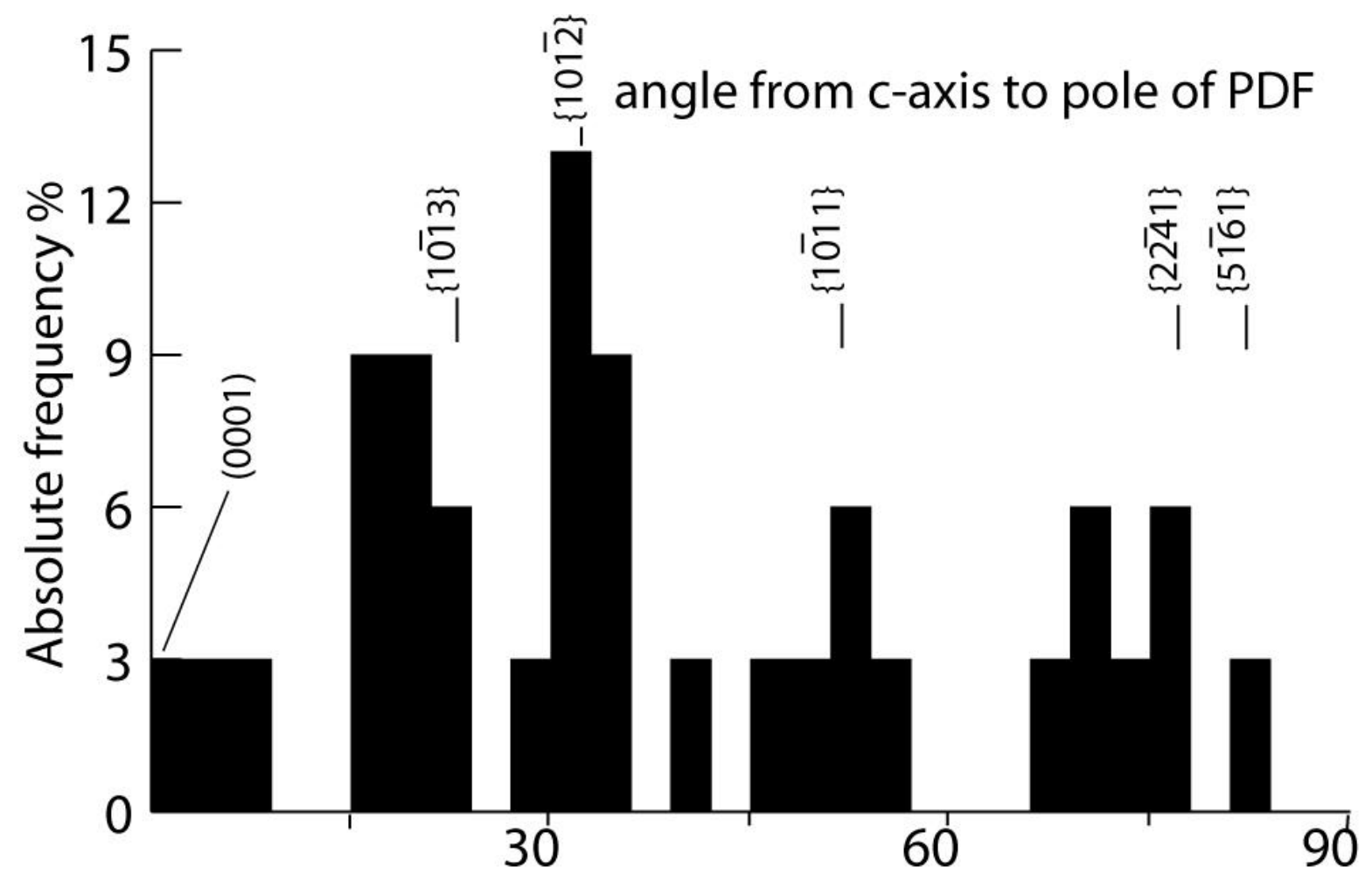

Fig 3.
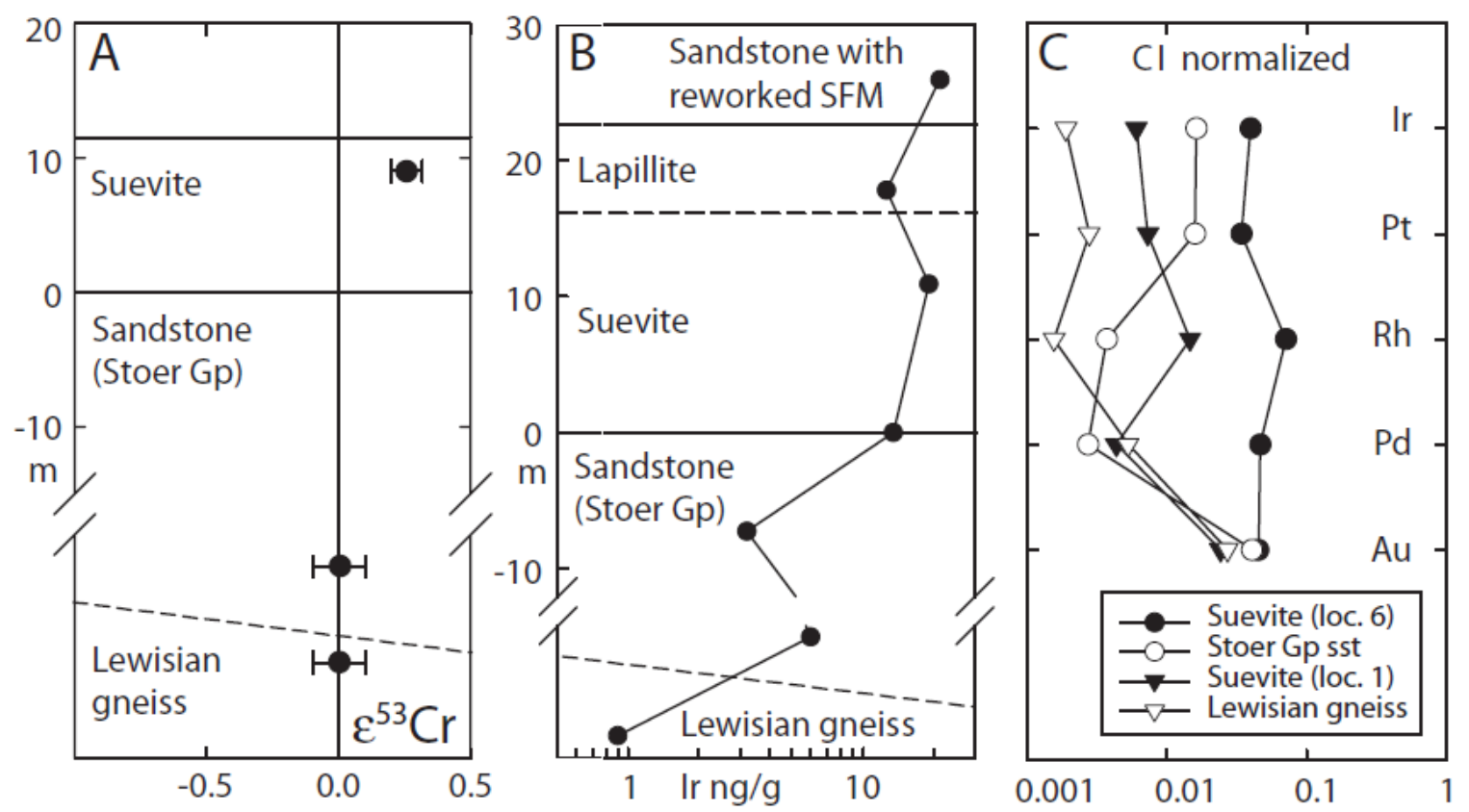

Fig 4. 